\title{
Novel HLA-alleles identified in populations of the Northern Caucasus
}

\author{
Maria A. Loginova ${ }^{1,2}$, Igor V. Paramonov², Andrey V. Rylov ${ }^{2}$ \\ ${ }^{1}$ The Rosplasma Center of Medical Research \& Industry, Kirov, Russia \\ ${ }^{2}$ Kirov Research Institute of Hematology and Blood Transfusion, Киров, Россия \\ Contact: Maria A.Loginova, Head, Stem Cell Donorship Department, Rosplasma, Kirov, Russia \\ E-mail: loginova-ma@rosplasma.ru
}

\section{Objective}

A study in genetic diversity of HLA alleles in populations of the Northern Caucasus.

\section{Materials and Methods}

High-resolution HLA typing of A, B, C, DRB1 and DQB1 loci was carried out by means of Sanger sequencing technique for 2,543 DNA samples from potential donors of hematopoietic stem cells, recruited in the Republics of Dagestan and Chechnya. To confirm and describe the new alleles, we used new pyrosequencing technologies (Roshe), next-generation sequencing (NGS, GenDx), and monoallelic sequencing (PROTRANS).

\section{Results and Discussion}

In the course of this study, we identified 15 new HLA alleles. Frequency of the new alleles in population is approximately 1: 170. The North Caucasian Republics are characterized by maximal frequency of new alleles among all the studied Russian populations, since these ethnic communities are underrepresented in bone marrow donor registries. This is related to the genetic profile of these populations. It should be noted that the 12 newly identified alleles are characterized by nucleotide substitutions which result into amino acid substitutions in domains constituting the peptide binding groove of
HLA molecules, thus being involved into the "friend-or-foe" recognition.

According to recent data, as by July 31, 2016, the nine novel alleles were registered by the WHO Nomenclature Committee for Factors of the HLA System: 3 HLA-loci A, 2 HLA-loci B, 1 HLA-loci C, 2 HLA-loci DRB1, 1 HLA loci DQB1. Interestingly, some of these alleles were identified in several non-related persons, i.e., $A^{\star} 26: 106, B^{\star} 57: 78, A^{\star} 24: 314$ were identified in two, five and seventeen cases correspondingly. This result suggests a turnover of these alleles in Russian population rather, than random genetic mutations. At present time, our laboratory is unable to identify specific allele differences for other 6 alleles as compared with known alleles.

\section{Conclusion}

The studies performed have shown relevance of further research in HLA-allele diversity among different Russian populations. A regional prevalence of HLA traits among potential HSC donors would increase efficiency of their matching to the patients at Russian clinics performing allogeneic stem cell transplantation.

\section{Keywords}

HLA-typing, Northern Caucasus, new alleles, genetic diversity. 


\title{
I Новые HLA-аллели в популяциях Северного Кавказа
}

\author{
Мария А. Логинова, Игорь В. Парамонов, Андрей В. Рылов
}

${ }^{1}$ Российский медицинский научно-производственный центр «Росплазма» Федерального медико-биологического агентства России», Киров, Россия

${ }^{2}$ Кировский научно-исследовательский институт гематологии и переливания крови Федерального медикобиологического агентства России, Киров, Россия

\section{Цель работы}

Изучение генетического разнообразия генов системы HLA в популяциях Северного Кавказа.

\section{Материалы и методы}

Проведено HLA-типирование локусов A, B, C, DRB1, DQB1 методом секвенирования (Abbott) в высоком разрешении, полученных в 2543 образцах ДНК от потенциальных доноров гемопоэтических стволовых клеток, привлеченных в республиках Дагестан и Чечня. Для подтверждения новых аллелей были использованы технологии пиросеквенирования (Rosche), NGS (GenDx), моноаллельного секвенирования (PROTRANS).

\section{Результаты и обсуждение}

В ходе проведенных исследований выявлено 15 новых аллелей, т.е частота выявления новых аллелей равна примерно 1:170. Популяции Северного Кавказа характеризуются самой высокой частотой выявления новых аллелей среди всех изученных российских популяций, что обусловлено особенностями их генетического профиля, а также тем, что представители данных популяций практически не представлены в мировых регистрах доноров. Следует отметить, что 12 новых аллелей из 15 выявленных - это аллели, содержащие нуклеотидную замену, которая привела к замене аминокислоты в доменах, образующих пептид-связывающую бороздку молекул HLA, и, следовательно, участвующие в процессе распознавания «свой-чужой».
По данным на 31 июля 2016 года, 9 новых аллелей зарегистрированы международным Комитетом по номенклатуре факторов HLA-системы BO3: 3 - по локусу A, 2 - по локусу B,1 - по локусу C, 2 - по локусу DRB1, 1 - по локусу DQB1. Важно отметить, что некоторые из указанных аллелей были выявлены у нескольких чело-

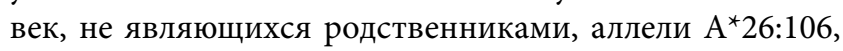
$\mathrm{B}^{\star} 57: 78, \mathrm{~A}^{\star} 24: 314$ обнаружены в двух, пяти и семнадцати случаях, соответственно. Это свидетельствует не о случайных мутациях в гене, а о циркуляции данных аллелей среди представителей данных популяций. На сегодняшний день для остальных 6 новых аллелей лаборатория не имеет возможности получить последовательность нового аллеля отдельно от уже известных аллелей.

\section{Заключение}

Проведенные исследования показывают актуальность дальнейшего изучения разнообразия HLA-аллелей у представителей различных российских популяций и расширения географии рекрутирования потенциальных доноров ГСК с охватом всех регионов Российской Федерации, что позволит увеличить эффективность подбора доноровГСК для пациентов российских клиник, нуждающихся в аллогенной трансплантации ГСК.

\section{Ключевые слова}

HLA-типирование, Северный Кавказ, новые аллели, генетическое разнообразие. 